Марко М. РАДУЛОВИЋ Институт за књижевност и уметност Београд
Оригинални научни рад

Примљен: 4. 11. 2020.

Прихваћен: 25. 2. 2021.

\title{
ЕСЕЈИ МИОДРАГА ПАВЛОВИЋА О СТАРОЈ СРПСКОЈ КНИЖЕВНОСТИ
}

\begin{abstract}
У раду ћемо анализирати Павловићеве есеје о старој српској књижевности објављене у књизи Огледи о народној и старој српској поезији на основу којих ћемо сагледати Павловићев оригиналан приступ овој традицији и боље разумети статус тог наслеђа у Павловићевој поетици. Истражићемо на који начин је Павловићево бављење средњовековном књижевношћу било у вези са медиевистичким замахом у другој половини двадесетог века, односно колико је допринело широј рецепцији те књижевности у савременој српској култури. С друге стране, испитаћемо како су Павловићева поетичка, естетска и културолошка схватања утицала на његова оригинална читања дела старе књижевности и назначити како су се таква тумачења одражавала у његовом песништву.

Кључне речи: средњовековна књижевност, Миодраг Павловић, есеј, (ауто)поетика, послератни модернизам.
\end{abstract}

Друга половина 20. века у српској књижевности била је богата песницима чија су поетичка усмерења и остварења често настајала из стваралачких додира са средњовековним наслеђем. Ипак, у српској култури, поезији и живој рецепцији ове полузаборављене епохе наше књижевности можда нико од песника није био толико повезан са овим наслеђем као Миодраг Павловић, који му је прилазио из различитих углова и са разнородним циљевима: као песник, антологичар и есејиста. Отуда је разумевање шире рецепције средњовековне културе у другој половини 20. века непотпуно без познавања Павловићевог поетског опуса, есејистичких увида и антологичарског поступка. У српској култури у којој је значај и утицај средњовековне епохе на (нову) српску књижевност повремено снажно био оспораван, Павловић је непоколебљиво веровао да писано средњовековно наслеђе, заједно са фолклорном књижевношћу, представља један од најстаријих извора наше традиције. Отуда је за њега било неприхватљиво свако скраћивање историјске перспективе јер би оно водило осиромашеној и непотпуној свести о сопстве-

*markorad984@gmail.com 
ном културном пореклу и трајању. У том погледу Миодраг Павловић био је близак схватањима Ернста Роберта Курцијуса, који је слична уверења гајио када је у питању латински средњи век и западноевропска књижевност. Павловићеви есеји о средњовековној књижевности објављени у књизи Огледи о народној и старој српској поезији били су посебно важни за откривање и реактуелизацију те „тамне” епохе наше књижевне историје, али представљају и речито сведочанство о Павловићевом личном односу према том наслеђу.

\section{У потрази за „заборављеним суштинама"}

У једном интервјуу Павловић истиче: „есеје сам почео да пишем у бурним педесетим годинама, када се присуством у јавности нешто могло и постићи. Поновно дефинисање наше културе обављало се и кроз нове валоризације наших песника. Кроз студије о песницима отварали смо питања, не само естетска, него и историјска, филозофска и политичка" (Павловић 2001). Готово од самог почетка свог стваралаштва песник Миодраг Павловић јавља се и као плодан есејиста који овај облик доживљава као „слободну форму размишљања о заборављеним суштинама” (Павловић 2001). Његови есеји пружају двоструку перспективу: с једне стране из Павловићевих разматрања о различитим феноменима српске литературе заиста је могуће прочитати историјске, философске па и политичке основе његове мисли, али изнад свега (ауто)поетичка сведочанства и естетске склоности драгоцене за потпуније разумевање његовог опуса; с друге стране, нека Павловићева тумачења представљају важан допринос историји српске књижевности и културе, доносе нова вредновања, оцртавају непримећене везе и могућности због чега постају неизоставан елемент самосвести српске књижевности, односно њене свести о сопственим „заборављеним суштинама”, свом трајању и традицији. Ова двострука потенција интерпретације присутна је и у Павловићевим есејима посвећеним средњовековној књижевности.

Павловићев поступак као есејисте такође карактерише настојање да посматране појаве доведе у довољно широк, али релевантан контекст. Тако када пише о средњовековној књижевности, он је посматра у односу према фолклорном стваралаштву, али и према епохама које јој последују. Другим речима, вредносне судове о тој епохи Павловић заснива кроз испитивање њеног места у ширем контексту српске традиције. Слично као што и саму ту традицију, њено значење и значај, одређује у оквирима светске културне баштине. Отуда је Павловић настојао да историју српске књижевности сагледа као целину која заузима своје место у ширем поретку светске књижевности, па за своју књигу Огледи о народној и старој српској поезији (Павловић 2000) каже: „Испитујући нашу, српску, књижевну традицију знао сам да је она део већих целина у чијим оквирима она представља особену вредност" (Павловић 2001). 


\section{Може ли средњи век да буде „савремен”?}

Павловићев поглед на средњовековну књижевност двоструко је условљен. С једне стране, њему је стало да продре до иманентних начела поетике средњовековне књижевности, како би је објективно сагледао; с друге стране, он зна да је услов да то стваралаштво постане интегралан и жив део традиције, успостављање слободног дијалога у коме ће се појаве те епохе сагледати из савремене визуре.

Есеји Миодрага Павловића о старој књижевности такође се могу читати као својеврстан прилог новијој културној историји јер представљају вредно сведочанство о положају и рецепцији средњовековне књижевности у другој половини 20. века. Наиме, Павловићев однос према овој епохи наше књижевности био је у јавности истовремено прихватан, али и снажно оспораван, док је сам писац јасно артикулисао бројне неразрешене филолошке, поетичке и теоријске недоумице које су пратиле реактуелизацију средњовековне књижевности у новом добу, односно тадашњу медиевистику.

Иако начелно превазиђен, Скерлићев суд о средњовековном књижевном стваралаштву као писмености, а не књижевности још увек је и у другој половини 20. века имао своје дејство и присталице (Скерлић 1997: 19). Наиме, средњовековна књижевност била је удаљена од савременог доба не само временски и језички, већ цивилизацијски и поетички, а након Другог светског рата испречила се и нова удаљеност: идеолошка. Стога видети у том наслеђу живу традицију која може бити подстицајна и пријемчива за савремене читаоце и ствараоце, није одувек био једноставан задатак. Иако је и у првој половини 20. века било песника који су у своје дело инкорпорирали ово наслеђе, тек су се, помало парадоксално, након Другог светског рата створили услови за ширу и потпунију рецепцију те књижевности. Она је пре свега била омогућена новим замахом у медиевистици и издавањем необјављених средњовековних текстова. Овакав научни помак срећно се сусрео са поетичким усмерењима послератних модерниста: шире песничко интересовање за традицију и, у оквиру ње, (полу)заборављене епохе, управо је у средњем веку нашло плодно тле. Један од водећих песника у тој реактуелизацији био је управо Миодраг Павловић. Као песнику њему је посебно било стало до средњовековне поезије и њеног потенцијалног значаја за савремене ствараоце и читаоце. Стога је једно од главних питања које је постављао, заједно са неким медиевистима, било: шта представља наше средњовековно песништво?

\section{Постоји ли средњовековна поезија?}

Питање о постојању средњовековне поезије, односно о томе где за том поезијом треба трагати и у ком степену је она блиска савременом схватању песништва показало се као веома значајно у рецепцији средњовековне књижевности у другој половини 20. века. Наиме, међу познаваоцима је постојало 
колебање да ли је средњовековни текст писан у прози или стиху, због чега су медиевисти и песници тога доба гајили заједничко уверење да је средњовековну поезију могуће наћи и у прозним жанровима какво је житије. Трагање за поетским одломцима у прозним средњовековним жанровима и потом њихово штампање у виду стихова у различитим антологијама подједнако су предузимали песници и научници.

Постојање песничких, реторско-лирских целина или фрагмената у нашим средњовековним житијима почела је да открива и да заступа као уверење тек у нашем времену генерација послератних песника и научника (Павловић 2000: 194).

У бројним антологијама средњовековни текстови штампани су као одломци у виду стихова. Антологичар би на основу сопственог суда одабрао она места за која је сматрао да представљају својеврсне поетске пасаже у житијном тексту и доносио би их издвојене из шире целине, графички представљене као стихове. Такав поступак није био без утицаја на смисао пренетог текста: изостављани су сви они делови за које би састављач проценио да су „недовољно поетски”, односно лишени ауторовог личног печата. Такође, издвајање одређене синтагме из тако донетог одломка за наслов, додатно је утицало на смисао пренетог текста. ${ }^{2}$ Павловић је још приликом састављања Антологије (Павловић 1964) био свестан начелних приговора који се могу упутити оваквом приступу, па их безмало 25 година касније у есеју „Наша средњовековна поезија” (Павловић 2000: 193-198), који представља својеврсну допуну и нови осврт на напомене које је изнео у предговору Антологији, поново разматра. У том огледу показује се да одређене неодумице везане за издвајање поетских фрагмената из ширих целина још увек нису решене. Павловић их сада још више истиче, постављајући питање о томе шта добијамо издвајањем онога што сматрамо песничким деловима неког ширег жанра и његовим штампањем у зборницима: да ли тиме боље упознајемо средњовековну епоху или пак условно речено стварамо ,јједан 'фантастични' књижевни жанр који у том виду заправо није ни постојао”. Оваква питања можда представљају и одјек критике Србљака (1970), односно начина издавања и научне обраде средњовековних текстова, Светозара Петровића (Петровић 2007: 5-47). Павловић не успева да пружи недвосмислен одговор на њих, као ни на основно питање шта је заправо средњовековна поезија, али не сумња да је песнички говор средњовековних писаца опстајао у једној врсти „отворене форме”, па на основу сопствене стваралачке и читалачке интуиције сматра да су наши стари писци „били дорасли за једну авантуру високе духовности”, а да је њихов „песнички говор био флуиднији од ликовног, и због тога, можда, прилагодљив за разне теме, па и пригодне, и на тај начин је остао вишеструко инспиративан све до данашњих дана" (Павло-

\footnotetext{
${ }^{1}$ Ђорђе Трифуновић, Из тмине појање (Трифуновић 1962); Ђорђе Радојичић, Старо сриско песништво IX-XVIII века (Радојичић 1966).

2 „Поетски фрагменти из старих рукописа издвајају се из свог контекста, често нимало литерарног, затим се преводе на данашњи језик, потом се ти преводи разламају у версете и објављују као песме под насловима које им дају приређивачи“ (Деретић 1997: 85).
} 
вић 2000: 198). Управо у инспиративности средњовековне књижевности, која се показује и на примеру његове поезије, лежи главни разлог Павловићевог интересовања за њу.

У поетичком настојању да се у средњовековној књижевности пронађу кристализације духовног искуства блиске савременом добу које су подстицајне за модерне ствараоце лежи и одговор на питање: због чега Павловић није тражио поезију тамо где се она најлакше могла наћи, наиме у литургијском корпусу црквене књижевности. У време састављања Антологије Павловић је признао да је имао најмање увида у како каже „литургијски арсенал” средњовековне поезије. Приликом писања есеја „Наша средњовековна поезија" ситуација је била ипак другачија. Објављен је Србљак, зборник средњовековних служби, канона и акатиста, за чији језик је Павловић признавао да представља „стари српски књижевни језик”, односно да је реч о „корпусу наше црквене поезије”. Међутим, то за Павловића није била поезија која би била блиска модерном сензибилитету и са којом би савремени песник могао да ступи у стваралачки дијалог, из простог разлога јер су ти текстови били ,лишени сваке могуће двосмислености, а тиме и могућности да имају дубину, или ореол поетичности у правом смислу” (Павловић 2000: 194). Стога он није одустао од тога да тражи средњовековну поезију на другим местима, чак и када су многи медиевеисти који су делили слична уверења, почели да коригују сопствене ставове. Видимо да се Павловић у свом трагању за средњовековном поезијом у различитим средњовековним жанровима није водио искључиво формалним метричким одређењима, већ и оним што је сматрао самом природом поетског израза, а то су према њему: дубина, двосмисленост, неочекиван потез маште и оригиналност.

Отуда можемо тврдити да Павловић у средњовековним текстовима није трагао за поезијом у строгом смислу, већ за поетским квалитетом текстова, који је налазио на жанровски различитим местима, баш као што га је могуће наћи и у прозним жанровима савремене књижевности. Другим речима, духовна авантура артикулисана у писаној уметности наших средњовековних предака и слободан дијалог са њом, били су главни покретачи Павловићевог интересовања за ову епоху. Управо зато је његов приступ неупитан и од изузетног значаја, упркос потенцијалним другачијим схватањима данашње науке о средњовековној књижевности. Наиме, Павловић није трагао у средњем веку за поезијом из научних разлога, већ пре свега из поетичких, а потом културолошких и напокон читалачких. Отуда је, изнад свих потенцијалних питања, за њега најважнија била „могућност да песничко завештање средњег века буде реално надахнуће нових песника”, а она се по њему „тек у наше време истински открива" (Павловић 2000: 198).

Управо есеј „Наша средњовековна поезија” показује да, иако слободан и оригиналан, Павловићев однос према средњовековној књижевности никада није био неодговоран ни наиван. Наиме, Павловић је гајио научни опрез и чувао се да осетљиво ткиво далеке књижевности не повреди сувише грубим поједностављивањима. Отуда је за њега постојање отворених проблема било чак и подстицајно, а свакако прихватљивије него симплификације или 
одбацивања којима би се богате потенције средњовековне књижевности инструментализовале и свеле у оквире наших тренутних потреба: „Литерарни патриотизам не допушта потпуно упрошћавање мисли о књижевности. Остајање при проблемима је плодотворније него пребрза решења која значе осиромашење књижевног фонда" (Павловић 2000: 195).

Управо зато постојање бројних питања, њихова отвореност и неразрешивост нису биле разлог због кога би Павловић одустао од читања и проучавања средњовековне књижевности, односно од настојања да ту епоху сагледа као интегралан део наше традиције који може бити подстицајан за ствараоце 20. века.

\section{Мит, фолклор, хришћанство}

У складу са својим интегралистичким погледима на традицију, Павловићу је посебно стало до веза, утицаја и блискости између писане средњовековне и фолклорне књижевности. Овакво усмерење проистиче из његовог настојања да у проучавању наслеђа прошлости трага за интегришућим факторима и линијама континуитета које од њега чине хетерогену али органску целину, односно традицију са непрекинутим трајањем. Проналажење блискости између ова два класична вида књижевног стварања у нашој прошлости значајно је обогаћено Павловићевим интересовањем за митологију, древна предања, ритуале и обредно искуство. Уочавањем да се испод тема и мотива хришћанске писане и усмене фолклорне књижевности могу крити дубље, заједничке митске слике и обрасци истовремено се уочава древност, али и универзалност оба вида књижевног стварања. А то су вредности до којих је Павловићу посебно стало. Отуда он неретко средњовековну књижевност и мотиве тумачи митовима и предањима који су знатно старији од хришћанског, не пропуштајући при том да покаже специфичност и стваралачку надоградњу хришћанске варијанте тих митова.

Тако је у његовој визури Теодосије писац „са великим литерарним осећањем и дубљим разумевањем митских условности" (Павловић 2000: 206-211). Павловић у Житију Петра Коришког увиђа ,једно посебно, чудно место којим Теодосије превазилази оквире библијског предања и, чини се, несвесно или не хотећи стиже до једне древне митологеме" (Павловић 2000: 209). Реч је о сцени у којој Петар Коришки након што је уз помоћ архистратига Михаила победио змију улази у њену пећину и ту заснива цркву. Павловићу није привлачно објашњење које каже да светац заснива цркву на месту своје победе над искушењем: „Једноставно би било тумачити да се тиме успоставља сопствена победа над највећим искушењем или помоћ 'архистратига' Михаила" (Павловић 2000: 209). Он посеже за ширим митским објашњењима ове сцене, истичући улогу коју змија има у египатској и иранској митологији, доводећи у везу подвиг Петра Коришког са блискоисточним митским представама о енергији васкрсења која долази из „свеопште мајке земље". Овај део Теодосије је могао преузети, Павловић сматра, управо из усменог предања о Петру Коришком. Без обзира на тачност оваквих запажања, 
значајно је да Павловићеву пажњу у средњовековном житију заокупља управо место за које он сматра да је блиско са народним предањем и још дубље са древним митолошким представама човечанства. То сведочи о природи његовог приступа који се често састоји из настојања да испод конкретних песничких слика и културолошких симбола уочи дубље, митске структуре и фрагменте на којима оне почивају, и тако покаже како конкретни симболи на нов и посебан начин исказују прастаре духовне доживљаје и поглед на свет.

Још значајније место за разумевање Павловићевог схватања средњовековне књижевности, али и његових аутопоетичких преокупација и промишљања јесте његово тумачење Данила Другог и његових, како их назива, „космолошких” идеја (Павловић 2000: 212-221). Павловић застаје на уводном исказу из Житија краљице Јелене где писац каже да је Бог утврдио „небеса мудрошћу и основа земљу ниначему" (Павловић 2000: 212). Павловић не сматра такав исказ само реторским обртом опште познатог става о божијем стварању „из ничега”, већ и философском рефлексијом коју је Данило поновио у Житију Стефана Дечанског, не налазећи му смисаоно подударне паралеле у Библији, већ у Ргведи и Аристотеловој Физици. Павловић истиче да га превасходно привлачи облик у коме средњовековни писац исказује своју идеју, као и вишак значења који је тим обликом добијен: „ништавило стварањем није укинуто, него са њим напоредо траје, чак и као његова (негативна) основа" (Павловић 2000: 216). Овакво читање драгоцено је за разумевање слике света коју нам доноси Павловићева поетика. Наиме, стварање и ништавило представљају два основна пола у његовим песничким визијама и он се тој теми враћао у различитим фазама свога стваралаштва. Једна од значајних Павловићевих песама „Балкански путопис” из Велике скитије (Павловић 1972) у целини је изграђена на контемплацији и опонирању (историјског) стварања и ништавила. Такође, своју песму „Из Данила Пећког” Павловић управо гради на увиду који је стекао читајући његово дело. Песма представља модерну, иронично осенчену варијацију већ помињаног увода

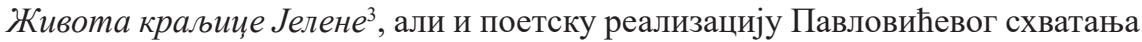
да се уз стварање увек јавља и ништавило као његова „негативна основа”:

Господ / небеса утврди / мудрошћу // а земљу основа / на Ничем // ту је / и свако од нас / пустио корен / насупрот / чуду / неисповедивом / што над главама / промиче / мрко (Павловић 1989).

По природи своје мисли, поетике и читалачког искуства Павловић је гајио посебно интересовање за оно што је сматрао митским сликама у средњовековној књижевности. Оне су по њему сведочиле о дубљим промишљањима писаца која нису увек могла да се искажу у оквиру строго утврђене схеме средњовековних књижевних жанрова, али и о остацима прастарих представа које су биле сачуване у самом језику и структури хришћанских симбола. Отуда су за Павловића таква места била посебно узбудљива, проширивала

\footnotetext{
3 ,Једини Бог богова и господ господара, свевидљиве и невидљиве твари творац, светлост неприлазна и живот у свима, утврдио је небеса мудрошћу и основа земљу ниначему“ (Павловић 2000: 212).
} 
су могућности читања једног дела, док су истовремено усложњавала нашу представу о старој књижевности и духовним преокупацијама њених писаца: „Ми верујемо да таква места - бременита значењем, или у свиленој чаури загонетке - чине већ саставне делове једног вредносног суда о књижевном делу, а највише је тако кад имамо посла са жанровски сложеним и мозаично компонованим житијским делима наше средњовековне књижевности" (Павловић 2000: 216).

Осим што је уочавао митске слике у средњовековној форми које су у ову књижевност по њему долазиле из народног предања или одговарајућих философских и духовних преокупација самих писаца, Павловић такође истражује потенцијалне утицаје које је средњовековна књижевност остваривала на фолклорно стваралаштво у есеју „Византијска култура и српска фолклорна традиција” (Павловић 2000: 199-205). Тако тумачећи песму „Опет крштење Христово” Павловић показује како је народни певач обогатио својом „наивном” фантазијом сцену Христовог крштења из синоптичких јеванђеља тако што је у њен опис унео осећање сопствене уроњености у космос и „радосно узбуђење", истовремено остајући дубински близак црквеном предању. Отуда Павловић високо вреднује народни доживљај мистерије вере и овакве фолклорне текстове инвентивно и сугестивно назива паралитургијским текстовима, закључујући: „Ова песма је пример успешног спајања усмене песничке традиције и искреног народног обожавања. Мада није канонска у својим детаљима, она приказује емоцију која се дубоко проживљава пред мистеријом Вере, па постаје прихватљив паралитургијски текст" (Павловић 2000: 205).

Овакви Павловићеви увиди говоре да је њему подједнако стало да верно прикаже све нијансе и посебности различитих видова артикулисања духовног искуства, али и да кроз уочавање (не)скривених веза, испод њих открије основну истину: да је човеково стваралаштво целовито и да се иза разноликости форми често налазе иста темељна питања и универзални садржаји.

(Пре)осмишљавање и конституисање појма традиције водило је песнике након Другог светског рата ка све већем окретању митологији и архетиповима који истовремено сублимишу и универзализују разнородна људска искуства. Песничко отварање митских слојева стваралаштва, културе, па и свакодневнице представљало је један од важних поетичких поступака у послератном модернизму. Отуда када Павловић средњовековне писце види као ствараоце са познавањем и осећањем митских релација, то виђење истовремено проистиче из његове особене тачке гледишта, али је и у дубинској сагласности са неким од основних поетичких начела послератног модернизма и, према томе, ефектан начин да се средњовековни писари учине ближим и привлачнијим савременим читаоцима и ствараоцима. 


\section{Стваралачка рецепција и (ре)интеграција средњовековља у (савремену) српску културу}

Када је у питању природа Павловићеве заинтересованости за епоху средњег века, она је била двострука. С једне стране, он је ослушкивао медиевистичка истраживања свог доба са свешћу о томе да многа филолошка, текстолошка, али и поетичка питања везана за ту књижевност нису решена. С друге стране, он се за то наслеђе интересовао као песник са израженом (само)свешћу о поетичким, естетским и културолошким питањима. Отуда и његово настојање да та дела одгонетне на сопствени начин, читајући их у свом кључу. Управо се такав приступ показао као најплодотворнији када је у питању рецепција средњовековне књижевности у новом добу, али и њен утицај на Павловићево песничко дело. Наиме, Миодраг Павловић понудио је изазовна, не строго гледано увек тачна, али изнад свега подстицајна тумачења средњовековних писаца и тако их довео у читалачки хоризонт свога времена. Такође, искуства стечена током сусрета са делима ове књижевности показала су се као важна за настајање неких његових значајних песама, па и читавих збирки са мотивима и темама из средњовековне књижевности. Отуда нам познавање Павловићевог мишљења о средњовековној књижевности пружа драгоцену помоћ за разумевање једне линије његовог певања. Подједнако својим стваралаштвом и тумачењима Павловић је на убедљив начин потврдио да средњовековље представља живу традицију која може бити подстицајна за савремене ствараоце.

Видели смо да се у свом проучавању средњовековне књижевности Павловић ослањао и на одређена медиевистичка сазнања свога времена какво је оно о постојању поезије у житијној књижевности. Без обзира што су та медиевистичка уверења касније била проблематизована, остаје чињеница да су она снажно деловала на ширу рецепцију средњовековне књижевности у другој половини 20. века. У том смислу, медиевистичка достигнућа тога времена имала су незанемарљиву улогу у формирању једне поетичке линије послератног модернизма, на чијем челу су били Васко Попа и Миодраг Павловић, чиме не само да су допринела широј популаризацији средњовековља, већ су створила и услове за његово укључивање у савремено књижевно стваралаштво.

На основу Павловићевог интересовања за необичне слике, језичке исказе и семантичке нијансе у делима средњовековне књижевности, показује се да њега интересују куриозитети. Односно, места која одскачу од општих представа и устаљених очекивања, и која, управо због тога, не само да чине особену вредност дела, већ и отварају могућности за његово другачије разумевање. Овакво тумачење подразумева индивидуалну перспективу која је дубоко условљена унутрашњим светом, односно духовним и поетичким преокупацијама самог тумача. Интерпретације које настају на основу таквих увида могу се схватити и као „погрешно читање” у Блумовом смислу, односно тумачење које на креативан начин наставља традицију. Видели смо да је у Павловићевом случају двојак начин на који таква читања продужавају традицију. С једне стране, она се материјализују у његовој поезији и постају 
саставни део песничког искуства друге половине 20. века. С друге стране, захваљујући таквим тумачењима средњовековна књижевност се отвара ширем кругу читалаца и добија могућност да постане интегрални део савременог искуства.

Павловићу није било стало до тога да износи објективне, опште познате чињенице о средњовековним текстовима чак и када оне савременом читаоцу нису биле довољно познате. Он је сматрао да је то задатак науке о књижевности. Есеј је за њега заиста представљао форму слободног размишљања која му је дозвољавала да дела средњовековне књижевности тумачи као и књижевност осталих епоха: трагајући за детаљима који су се чинили занимљивим и релевантним, са којима би и савремени читалац могао да ступи у дијалог. Другим речима, Павловић је средњовековну књижевност тумачио као саставни део и живи потенцијал традиције. Отуда је значајно допринео њеној рецепцији. За Павловића песника, мислиоца и читаоца вредност средњовековне књижевности постоји пре свега уколико је са њом могуће комуницирати у различитим временима, из перспективе удаљених поетика и са другачијих културолошких позиција. Таква комуникација подразумева неспоразуме, погрешна читања, али и креативне и плодоносне сусрете. Као што је уосталом случај са сваком правом књижевношћу. Реч је напокон о комуникацији која се налази у самој основи чувања и стваралачког настављања традиције. А Миодраг Павловић уједно је чувао и на стваралачки начин продужавао средњовековно наслеђе у традицији српске књижевности.

\section{ЛИТЕРАТУРА}

Деретић 1997: Ј. Деретић, Поетика српске књижевности, Београд: „Филип Вишњић".

Павловић 1964: М. Павловић, Антологија српског песништва (XIII-XX век), Београд: СКЗ.

Павловић 1972: М. Павловић, Велика Скитија и друге песме, Београд: СКЗ.

Павловић 1989: М. Павловић, Кюига старословна, Београд: СКЗ.

Павловић 2000: М. Павловић, Огледи о народној и старој српској поезији, Београд: Просвета.

Павловић 2001: М. Павловић, Наша историја се стално кида, Глас јавности, 22. 4. 2001. Интервју водила Оливера Ђурђевић. http://arhiva.glas-javnosti. rs/arhiva/2001/04/22/srpski/I01042102.shtml, приступљно 27. 10. 2020.

Петровић 2007: С. Петровић, О издавању средњовјековног пјесничког текста, y: Списи о старијој књижевности, Београд: Фабрика књига.

Радојичић 1966: Ђ. Сп. Радојичић, Старо српско песништво IX-XVIII века, Крушевац: Багдала.

Скерлић 1997: Ј. Скерлић, Историја нове српске књижевности, Београд: Завод за уџбенике и наставна средства.

Трифуновић 1962: Ђ. Трифуновић, Из тмине појање - стари српски песнички записи, Београд: Нолит. 
Marko M. Radulović

\title{
MIODRAG PAVLOVIĆ'S ESSAYS ON MEDIEVAL SERBIAN LITERATURE
}

\begin{abstract}
Summary
Miodrag Pavlović offered challenging, strictly speaking not always exact, but above all inspirational interpretations of Medieval authors, thus bringing them into the field of view of readers of his time. Furthermore, the experiences gained upon encounter with the works of this literature proved to be important for writing some of his significant poems, and even entire collections with Medieval motifs and themes. This is why knowing Pavlovićs perception of Medieval literature provides precious insight into the understanding of one line of his poetic opus. Equally with his original works and interpretations, Pavlović convincingly confirmed that Medieval times represent a live tradition which can be inspiring for contemporary authors.
\end{abstract}

